\title{
Efficacy of Entrepreneurship Education, Intraprenuership and Students' Career Reflections
}

\author{
Kowo Solomon Akpoviroro, Olusegun Adeleke Oba Adenuga, Akinbola Olufemi Amos, \\ Taiwo Tolulope Olaoluwa
}

\begin{abstract}
Entrepreneurship Education has emerged as an area of research. However, despite the substantial growth in these impact studies over recent years, the empirical findings remain mixed, conflicting and inconclusive. Moreover, when career outcomes are addressed in impact studies, the focus is on entrepreneurship as a career, while Entrepreneurship Education (EE), broader career implications remain unexplored. The objectives of the study are to investigate the effects of Participation in Entrepreneurship Education on Career reflection and also to examine the effect of Students Intentions on Entrepreneurship and Intraprenuership. 110 copies of questionnaire were administered to the employees of Center for Entrepreneurship Studies of three Universities in Nigeria; they are (i) Center for Entrepreneurship Kwara State University Malete Nigeria (ii) Center for Entrepreneurship Lagos State University Nigeria (iii) Center for Entrepreneurship Ogun State University Nigeria to get primary data that treated and tested appropriate research questions and hypotheses accordingly. Analysis of variance (ANOVA), correlation efficient and regression analysis was employed. The yamane formula was used to determine the sample size. The study found out that Participation in Entrepreneurship Education affect Career reflection and Students Intentions affect Entrepreneurship and Intraprenuership. The findings revealed that Entrepreneurship Education is career exploration intervention that enables career reflection on career choice and future work selves. When students take part in Entrepreneurship Education, it can potentially be a process of transformational learning. The study recommend Entrepreneurship Education as a career reflection, this impact will have implications for students' future careers. Consequently, Entrepreneurship Education has the potential to impact how students behave in their future careers and how they reflect upon these.
\end{abstract}

Keywords: Entrepreneurship Education (EE), Career Reflections, Students Intentions, Intrapreneurship.

\section{JEL Classification: L26, M53, M}

Kowo Solomon Akpoviroro (PhD), Department of Business and Entrepreneurship, Kwara State University, Malete Nigeria, e-mail: kowosolomon@gmail.com

Olusegun Adeleke Oba Adenuga (PhD), National Open University of Nigeria, Department of Educational Foundation

Akinbola Olufemi Amos (PhD), Department of Business Administration, Federal University of Agriculture, Abeokuta

Taiwo Tolulope Olaoluwa (PhD), Department of Educational Foundations and Curriculum, Amadu Bello University Zaria, Nigeria 


\section{Introduction}

\section{Background to the study}

There is a need to go beyond the narrow focus of 'producing' entrepreneurs and to take a broader perspective on the implications EE has for students' careers. EE can be a space for career exploration that leads to career reflection, in which students discover more about themselves, about entrepreneurship, and about their career preferences. This is the background for focusing on students' career reflections in this paper and which led to the following overarching research question: How does participation in entrepreneurship education impact students' career reflections? To address this, the paper draws upon the literature on career development and investigates the potential of $\mathrm{EE}$ as a career exploration intervention that triggers students' career reflection. Deciding in which direction their career should go is a major developmental task for adolescents and young adults (Bell \& Bell, 2016; Sanni \& Akinbola, 2018; Branson, 2010). Finding and pursuing a chosen career can be an overwhelming decision to make, but it is also a very important one. Work represents a central aspect of life across societies and cultures, as it provides a means of survival and an arena for cultivating social relationships, a sense of identity and meaning. Career development and the emergence of vocational identity have consequently been established at the core of contemporary career theory. Progress towards career development and a vocational identity is of great importance in a person's life and a lack of progress can have severe consequences. Research shows that struggling with one's own career identity, being unemployed, and having an unfulfilling career have very negative effects on an individual's well-being (Nabi et al, 2018; Kowo \& Sabitu, 2018). The time as a student in higher education should accordingly be one of self-exploration, change and growth in terms of both personal and career development. It is a time when it is important to engage in exploration of different career trajectories and to reflect upon one's future career opportunities. The importance of career exploration and reflection implies that higher education needs to arrange activities that promote this among students; i.e., career interventions that trigger career development through exploration and reflection. Career counseling during tertiary education has been suggested as one means of career exploration that stimulates career development (Ranch \& Hulsink, 2015), and so includes internships as integrated parts of higher education degrees (Krueger, 2017). This study sets out to investigate the potential of EE as a career exploration intervention and as an arena for career reflection. According to Fayolle \& Gailly (2015), a learning environment that supports career development is characterized by a practice-based and inquiry-based curriculum and provides opportunities to engage in career dialogue. The point of departure for this study is that EE in its most active forms meets these characteristics and thereby could function as a career exploration intervention that enhances career development through career reflection. EE has many variations and differs in terms of objectives, target group, content, pedagogies and assessments (Garba, 2010; Hair et al, 2014). However, children and young adults spend far more time in school and have less opportunity to acquire practical work experience in everyday life. EE as a career exploration intervention provides an opportunity to overcome this challenge. This study seek to answer the following research questions (i) Does Participation in Entrepreneurship Education affect Career reflection (ii) What is the effect of Students Intentions on Entrepreneurship and Intraprenuership.

\section{Literature Review}

\section{The Concept of Entrepreneurship}

In 1732, the Irish economist Richard Cantillon used the concept of entrepreneurship in reference to individuals who are ready to carry out types of arbitration concerning the financial risk of a new venture (Longra \& Strand, 2018; Moberg et al, 2014; An \& Kang, 2016; Al Bulushi \& 
Bagun, 2017; Douglas \& Fitzsimmons, 2013). Entrepreneurship requires more studies to indicate and define its main elements, for despite the efforts of previous studies, there is no satisfactory definition (Sanni \& Akinbola, 2018; Garba, 2010). There is no doubt that the majority of studies on entrepreneurship revolve around the complexity of this term and the dialectics that have been raised about its definition, despite the existence of hundreds of studies (Lorz et al, 2013; Kpoveta \& Agbomah, 2009). Baumol and Strom (2007) mentioned that the concept of entrepreneurship is multi-dimensional. In this vein, there are several definitions of the concept. In addition, studies related to the definition of entrepreneurship and its role in the economy can be categorized in different ways such as chronology, in the school of thought and jobs attributed to entrepreneurs (Krueger, 2017). Longra and Strand (2018) argued that many factors influence developing a comprehensive concept for entrepreneurship. Some of these factors are related to the culture, the economy or the society. Because social and economic factors are not consistent, according to the surrounding environment, it is fair to say that there is not yet a comprehensive definition of the concept of entrepreneurship, which includes all types and characteristics of entrepreneurship. Krueger (2017) indicated that entrepreneurship is a multifaceted phenomenon, analyzed as a process, resource or a state-of-being. According to Akinbola and Ogunaike (2015), the reason behind not developing a global definition is that entrepreneurship has been documented in various disciplines, resulting in many opinions about its meaning. Entrepreneurship is the capacity of an individual to transform ideas and suggestions into action. It includes the capability to create, innovate and take risks in order to achieve objectives and to plan and manage projects (Bell and Bell, 2016; Sanni \& Akinbola, 2018; Branson, 2010).

\section{The importance of career development in higher education}

As discussed above, progress towards career development and a vocational identity has substantial implications for an individual's well-being later in life. However, in an educational context, it also has more immediate implications in terms of retaining the motivation to graduate from higher education, as well as for the important school-to work transition. Statistics suggest that student drop-out and school-to-work transition are major challenges, both in the Nigeria and Africa contexts. In Nigeria, half of students do not complete their degree in the nominal study length (Ojeaga \& Owolabi, 2011). Career indecision and subsequent drop out from higher education have major consequences for both the individual and society. Immense investments are being made into higher education today and increasing the number of individuals holding tertiary education qualifications is at the top of policy agendas4 (Akinbola \& Ogunaike, 2015). The increasing student dropout rates are working against this goal and are also a major cost burden. It has long been acknowledged that goals and commitment towards a career are important for students' decisions on whether to persist with, or drop out from, their educational process (Adenuga, 2009; Fretshner \& Lampe, 2018; Liguori et al., 2019; Garba, 2010). Hence, graduates face the risk of unemployment and underemployment, with the negative consequences these have for career prospects and well-being (Oviame \& Anarberokhai, 2008; Kowo \& Sabitu, 2018).

\section{Entrepreneurial behavior through intrapreneurship}

According to the above definition of entrepreneurship, it takes place in the context of creating new organizations. However, the behavior and processes that resemble entrepreneurship can be present within existing organizations and contribute to increasing the competitiveness of companies (Longra \& Strand, 2018; Moberg et al, 2014). The definition of entrepreneurship based on the individual-opportunity nexus (Jones \& Penaluna, 2013; Elet, Aderson \& Wennberg, 2015) is also accepted in the intrapreneurship literature (Krueger., 2017). Hence, since entrepreneurship and intrapreneurship are viewed as similar but separate behaviors in this study, there is a need for two separate definitions. Drawing upon the previous definition of 
entrepreneurship, intrapreneurship is accordingly defined as the discovery, evaluation and exploitation of opportunities for new combinations in the context of an existing organization (Gielnik, 2017; Baeet et al, 2014)

\section{The emergence and evolution of entrepreneurship education as a research field}

There has been an exponential growth in EE over the past decades. Since the first occurrence of Entrepreneurship courses in the US in the middle of the twentieth century (Lorz et al, 2013; Kpoveta \& Agbomah, 2009), EE is now a frequent feature worldwide and at all education levels. With the rise of entrepreneurship as a research field, research on EE has emerged as a sub-field of entrepreneurship that aims to describe and understand the development that is taking place.

As a sub-field of entrepreneurship, EE research has developed in parallel and has been influenced by the debates taking place within entrepreneurship research. Discussions about whether entrepreneurs are born or made have had implications for debates within EE research on whether entrepreneurship can actually be taught (Oviawe \& Anarberokhai, 2008). Logically, if entrepreneurs are principally born and are a result of inherited personality traits and characteristics, the objective of EE would mainly be to supply the business-specific knowledge necessary for starting a venture (Kowo \& Adenuga, 2019).

\section{The Impact of Entrepreneurship Education on Career Reflections}

As described in the literature review, there are many different outcome measures that are relevant when researching EE impact. Consequently, EE has the potential to impact how students behave in their future careers and how they reflect upon these. This reflection is the topic of this sub-chapter, which takes a closer look at two career-related outcome measures in EE, namely career choice intentions and career reflections. Given the importance of new venture creation for economic growth and development, both the entrepreneurship research community and policymakers have been eager to understand this particular career choice in order to encourage entrepreneurship. As the general understanding of entrepreneurship has moved away from believing that entrepreneurs are born with specific personality traits and characteristics (Baeet et al, 2014), the prevailing understanding of an entrepreneurial career choice is that it is something that can be influenced. The literature suggests that this career choice, among other factors, is influenced by exposure to and prior experience of entrepreneurship (Baumol \& Strom, 2007; Sanni \& Akinbola, 2018; Garba, 2010). This paper examines how EE can provide such exposure to entrepreneurship and thereby make students reflect upon their careers. EE is not just about "producing" entrepreneurs and creating more start-ups. Obviously, this is part of the objective, but as one of eight key competences for lifelong learning (Atakpa, 2011) entrepreneurship is essential for everyone, whether one plans to start a new company or to engage oneself in developing social enterprises or non-profit organizations. However, this career aspect does deserve more attention in EE impact research. The same applies to the impact EE has on intrapreneurship, which has only been addressed in a few empirical studies (Fayolle \& Gailly, 2015; Hytti \& Heinonen, 2013).

\section{Career Reflections and Future Work Selves}

Students in higher education are in a phase of their life when career development is central (Elert, Aderson \& Wennberg, 2015; Sanchez, 2013). Career exploration is positively associated with career commitment (Zampetakis et al, 2015), which refers both to making a choice as well as identifying with it. The third process, reconsideration, refers to the opposite, namely reexamining current commitments. Reconsideration is viewed as a critical process in identity development, and can have both positive and negative aspects (Garba, 2010). On the positive side, career reconsideration can lead to career flexibility, with openness to alternative careers 
that lead to more suitable commitments in the long term perspective. On the negative side, career reconsideration can lead to self-doubt and career indecisiveness if someone is not able to advance from reconsideration, to exploration, and to new commitment to other career opportunities. Thus, the processes of career exploration, commitment and reconsideration, and the reflection that takes place within these, are vital for career development. In a labor market that is increasingly boundary less and characterized by uncertainty and frequent career transitions (Valerio, Parton \& Robb, 2014), it is critical to be proactive in career development. Such proactivity has been linked to higher job satisfaction, higher salaries and faster career progression (Fretshner \& Lampe, 2018), and it is consequently important that students are given opportunities for career exploration during higher education to promote their career development. Career exploration lays the foundation for two main constructs in this study, namely career reflection and future work selves. Career reflection is, as the term suggests, reflection upon one's own career opportunities. It is defined as a core career competency and refers to the competency to be able to reflect on personal capacities and motivations in one's own career (Hair et al, 2014; Bell \& Bell, 2016). The career reflection that takes place during career exploration activities or interventions has implications for the two other processes of career commitment and reconsideration in Akinbola \& Ogunaike (2015) model of career development. Career exploration is essential for students' career development and should be encouraged in higher education. Both career counselling (Ojeaga \& Owolabi, 2011) and internships (Ranch \& Hulsink, 2015) have consequently been suggested as potential career exploration interventions in higher education. According to Kpoveta \& Agbomah (2009), it is important that the curriculum helps students make connections between school subjects, different types of occupations and the labor market in the surrounding environment. Further, Adenuga (2009) emphasize the importance of a practice-based and inquiry-based curriculum, in which students have the opportunity to engage in career dialogue.

\section{Measuring Impact in Entrepreneurship Education Research}

EE impact should be studied quantitatively in order to avoid reduced internal validity. Prior EE impact research has received considerable criticism due to the lack of methodological rigour (Baeet et al, 2014; Fayolle \& Gailly, 2015; Lorz et al, 2013; Moberg et al., 2014). Revisiting seminal contributions to intervention studies in social science by Kowo \& Adenuga (2019) and Ojeaga \& Owolabi (2011), as well as recommendations in educational research (Jones \& Penaluna, 2015), the advice on educational impact research is clear: interventions, either pedagogical or otherwise, should be studied through experimental design that employs control groups and pre-test post-test design. It can be challenging to organize pre-tests before a course starts since students might not be on campus. Nonetheless, it has severe implications for what we can claim to know about EE impact. SLR literature shows, narratives about the accumulated knowledge on EE impact cannot be supported by evidence-based studies. This is a critical challenge for an area in search of legitimacy, as a research field, in education institutions, and among governments and policy makers (Fayolle \& Gailly, 2015; Nabi et al., 2018). If EE is to continue its growth, it is vital to provide robust empirical evidence to its stakeholders (Nabi et al., 2018; Ranch \& Hulsink, 2015; Moberg et al, 2014), and the findings of the SLR paper support this claim.

\section{Theoretical Review}

\section{Resource Based Theory (RBT)}

Edith Penrose (1959) developed the Resource Based Theory (RBT), which examines the role of resources in the growth or empowerment of company hierarchy. She describes "the physical items which a company purchases, rents or provides for its own use and the general population are enlisted according to conditions which make them an appropriate part of the company" 
(Kellermanns et al., 2016). At first, the RBT grew in the field of management. Nag et al. (2007) have developed the concept of vital administration. They indicated that core management handles the significant anticipated and emerging operations of general supervisors, including the use of resources to enhance business efficiency by owners. "Therefore, essential administration directs managers and corporation manages persons or groups of individuals acting freely or as a function of a company structure, forming or reinventing new associations" (Sharma \& Chrisman, 1999; Kellermanns et al., 2016). The RBT examines the suitability of the assets of companies to achieve strong efficiency with their characteristics. RBT's most distinctive achievement is the plan of criteria that must be met to ensure the company's continued advancement of assets (Kellermanns et al., 2016). Barney (1991), who declared that a company's assets in respect to human capital preserved its upper hand, produced one of the most convincing texts of essential administration in history. He explained that a company is said to be upper-hand when it updates a value scheme which any current or potential competitor executes at the same moment, and when those various companies are unable to copy the benefits of that scheme. Early RBT work identified that the company is a complex asset-based structure (Kellermanns et al., 2016). In any case, RBT has become the world's main view for key management assessments (Peteraf, 1993), and having an RBT-business interface is a minimal requirement in providing a "research setting" for observational work. Because most asset-based studies fail to account for the thinking of the company, RBT fails to a considerable extent to include imagination and entrepreneurial demonstration in the area of carrier intention (Barney et al., 2001). The company's resource basis perspective (RBV) has proven to be one of the most commonly used hypotheses in management and entrepreneurship studies. The central premise of RBV is that the company produces upper hands, thanks to its outstanding asset structure (Nag et al, 2007).

\section{Empirical Review}

Hytti and Heinenem (2013) in there study found that Learning about entrepreneurship is often referred to as awareness education, through which entrepreneurship is explored as a societal phenomenon and it was revealed that there is a positive effect between participation in EE and carrier reflection. The approach is theoretical in its form and explores the 'what's' and 'whys' of what entrepreneurs do and the implications of entrepreneurship for the economy and society. Fretshner and Lampe (2018) studied Learning about myths, team roles and theoretical perspectives such as the individual opportunity nexus, effectuation, there findings revealed that graduates face the risk of unemployment and underemployment, with the negative consequences these have for career prospects and well-being. There findings is align with the findings (Gielnik, 2017) and (Atakpa, 2011). Donnellon and Ollila (2014) research revealed that there is general understanding of the phenomenon and its implications, and on knowledge rather than skills and experience. In a review of 117 course outlines and syllabi in the US and UK, Jones \& Penaluna (2013) found that learning about entrepreneurship was the primary form of approach in 59\% of the courses examined. Gielnik et al, (2015) found that EE should involve a portfolio of practices by which entrepreneurship is taught as a method that lets students develop a bias for action and explore authentic entrepreneurial processes in an experiential and iterative manner. Hence, learning through entrepreneurship entails learning through doing entrepreneurship in practice. Students thereby acquire entrepreneurial competencies and skills that are applicable beyond the entrepreneurial context, as described in, for example, the Entre Comp framework by Bacigalupo et al, (2016), or in the value creation perspective of Branson (2010). However, the strong emphasis on actionable, experiential and practice-based pedagogies has also raised concerns among EE scholars. Kuratko et al. (2005) in his study revealed that some factors influence the size and depth of business activities which are carried out within the company to pursue corporate entrepreneurship, and these variables are identified 
as an antecedent for the corporate entrepreneurial activities. Yildiz (2014) found participation in $\mathrm{EE}$ as one of these antecedents. EE can be regarded as a major driver of entrepreneurial intention and career reflection. Okta et al, (2015); Brettel et al. (2015); Fayolle et al. (2010) and Shepherd et al. (2010) found that EE has a key role to play in promoting entrepreneurial Intention. Several previous studies have examined the connection between different cultural and entrepreneurial elements in different contexts. Yildiz (2014) found that the capacity of an organization to create and retain an entrepreneurial posture depends on its career reflection. Kellermanns (2007) and Cherchem (2017) in there study proved that career exploration is essential for students' career development and should be encouraged in higher education. Career, counseling and internships have consequently been suggested as potential career exploration interventions in higher education, it also revealed that the curriculum helps students make connections between school subjects, different types of occupations and the labor market in the surrounding environment. Kalmuk and Acar (2015) found that EE can helps an organization play an active role in intelligence generation, information dissemination and in adapting to market shifts so that EE can turn into an advanced market which enhance Career reflection and Intrapreneurship.

\section{Methods}

This section discusses the methodology of the study and research design. It introduces research philosophies, research approach, data sources, and research design. Additionally, it details the use of the survey method, sampling design, questionnaire development, questionnaire design and measurement. In addition, the techniques of the data collection employed and the application of the study strategy are covered. The expo factor method was used. Furthermore, the current quantitative phase of the data collection, through which a description of the methods used in implementing the quantitative phase in this study are provided. The argumentation begins with the justification behind selecting a sample survey method. The study adopts a selfadministered survey for data collection, as detailed. Moreover, the research focuses on the survey design, the pilot study applied to test different issues in the study strategy and the study's latent variables. In addition, questionnaire was the research instruments for this study' description and their related indicators are provided. The research's data preparation technique employed to verify the data accuracy was discussed, followed by the data preparation, which includes dealing with missing values and outlier issues. The issue of the methodology of choosing the methods of data collection to be used for the study basically depends on the fact that what are the aims and objectives of the research under consideration (Giddings \&Grant, 2006; Gill \& Johnson, 2010). Primary data was used for this study. A cross-sectional design was adopted. The study population refers to the entire number of employees of Center for Entrepreneurship Studies of three Universities in Nigeria; they are (i) Center for Entrepreneurship Kwara State University Malete Nigeria (ii) Center for Entrepreneurship Lagos State University Nigeria (iii) Center for Entrepreneurship Ogun State University Nigeria. For this study the sample size is determined using Yamane formula. This formula is concerned with applying a normal approximation with a confidence level of 95\% and a limit of tolerance level (error level) of 5\%. (Easterby- Smith, Thorpe \& Jackson, 2011)

Therefore, the sample size is determined by

$\mathrm{n}=\left[\frac{N}{1+N e^{2}}\right]$

where $\mathrm{n}=$ the sample size

$\mathrm{N}=$ population

$\mathrm{e}=$ the limit of tolerance 
Therefore, $\mathrm{n}=\frac{152}{1+152(0.05)}^{2}$

$$
\begin{aligned}
& =\frac{152}{1+152(0.0025)} \\
& =\frac{152}{1+0.38} \\
& =\frac{152}{1.38} \\
& =110.14 \\
& =110 \text { respondents (approximately) }
\end{aligned}
$$

A sample of one hundred and ten (110) employees out of the one hundred and fifty two (152) employee population was selected, the simple random sampling technique was adopted. Towards this end, the test re-test reliability approach was adopted for the convenience of the researcher. Reliability was ensued by Cronbach's Alpha of 0.932 . The detail of the reliability statistics table is shown below.

Table 1 Reliability Statistics

\begin{tabular}{|l|l|}
\hline $\begin{array}{l}\text { Cronbach's } \\
\text { Alpha }\end{array}$ & N of Items \\
\hline .932 & 42 \\
\hline
\end{tabular}

Source: Field Survey 2020

Cronbach's Alpha coefficient is .932 for the 42 items that were analyzed together. It therefore indicates that the research instrument used for this study is highly reliable as it is more than the generally accepted reliability score of 0.7 . The data was analyzed using manual and electronic based methods through the data preparation grid and statistical package for the social sciences, (SPSS). The utilization of structured grids allows specific responses to be located with relative ease and facilitate the identification of emerging patterns (Creswell, 2009).

Table 2 Distribution of respondents and response rate

\begin{tabular}{|l|l|l|}
\hline $\begin{array}{l}\text { Respondents } \\
\text { Occupation }\end{array}$ & $\begin{array}{l}\text { Questionnaire administered } \\
\text { (sampled) }\end{array}$ & $\begin{array}{l}\text { Percentage of total response } \\
(\%)\end{array}$ \\
\hline Top Level & 10 & 52.7 \\
\hline Middle Level & 48 & 36.3 \\
\hline Level Lower & 33 & 11.0 \\
\hline Total & 91 & 100.0 \\
\hline Gender/Category & Questionnaire administered (sampled) & $\begin{array}{l}\text { Percentage of total response } \\
(\%)\end{array}$ \\
\hline Male & 40 & 44.0 \\
\hline Female & 51 & 56.0 \\
\hline No of Returned & & \\
\hline No of Not Returned & & \\
\hline $\begin{array}{l}\text { Total no of } \\
\text { Questionnaires }\end{array}$ & 191 & \\
\hline
\end{tabular}

Source: Field Survey 2020 
Data analysis and Hypothesis Testing

Table 3 The Descriptive statistics of Entrepreneurship Education and Students' Career Reflections

\begin{tabular}{|c|c|c|}
\hline Responses & \multirow[b]{2}{*}{$\begin{array}{l}\text { Total } \\
(\mathbf{N})\end{array}$} & \multirow[b]{2}{*}{ Mean } \\
\hline Participation in Entrepreneurship and Career Reflection & & \\
\hline $\begin{array}{l}\text { The format of the EE course provided students with both subject specific } \\
\text { Knowledge and tangential skills that is important for their future careers. }\end{array}$ & 91 & 3.56 \\
\hline $\begin{array}{l}\text { Participation in EE impact students' career preferences for } \\
\text { entrepreneurship }\end{array}$ & 91 & 3.68 \\
\hline $\begin{array}{l}\text { When students take part in EE, it can potentially be a process of } \\
\text { transformational learning. }\end{array}$ & 91 & 3.89 \\
\hline $\begin{array}{l}\text { The challenge aspect of the course and the opportunities for reflection } \\
\text { appear to have activated reflections on how new insights could be applied } \\
\text { in their present and future careers, but also expand their vision of their } \\
\text { future careers. }\end{array}$ & 91 & 3.99 \\
\hline $\begin{array}{l}\text { EE serves as a space for career reflection, where students learn more about } \\
\text { themselves, about entrepreneurship, about the workplace, and about their } \\
\text { opportunities in future careers. }\end{array}$ & 91 & 3.99 \\
\hline $\begin{array}{l}\text { EE and Students Intentions Towards Entrepreneurship and } \\
\text { Intrepreneurship }\end{array}$ & Total & Mean \\
\hline \multirow[t]{2}{*}{$\begin{array}{l}\text { Business planning course has on the preferences for entrepreneurship and } \\
\text { intrapreneurship. }\end{array}$} & 91 & 3.68 \\
\hline & 91 & 3.78 \\
\hline $\begin{array}{l}\text { EE had a positive impact on students' entrepreneurial intentions for those } \\
\text { who had participated in EE in higher education. }\end{array}$ & 91 & 3.56 \\
\hline $\begin{array}{l}\text { There was a positive relationship between intentions towards } \\
\text { entrepreneurship, intrapreneurship and international mobility, indicating } \\
\text { common underlying variables. }\end{array}$ & 91 & 3.78 \\
\hline $\begin{array}{l}\text { Studies take a rather narrow approach to studying career impact and } \\
\text { primarily focus on entrepreneurial intention and actual entrepreneurial } \\
\text { behavior through nascence and new venture creation. }\end{array}$ & 91 & 3.75 \\
\hline $\begin{array}{l}\text { Exploring the learning process of design thinking in an EE course that } \\
\text { combines entrepreneurship and technology enhances, intrapreneurship }\end{array}$ & 91 & 3.58 \\
\hline
\end{tabular}

Source: Field Survey 2020

\section{Results}

Test of Hypotheses and Discussion of Results

Hypothesis 1:

$\mathbf{H}_{\mathbf{0}}$ : $\quad$ Participation in Entrepreneurship education does not affect career reflections

HI: Participation in Entrepreneurship education affects career reflections 
Table 4 Model Summary

\begin{tabular}{|c|c|c|c|c|c|}
\hline \multirow[b]{2}{*}{ Model } & \multicolumn{5}{|c|}{ Change Statistics } \\
\hline & $\begin{array}{l}\mathrm{R} \text { Square } \\
\text { Change }\end{array}$ & F Change & df1 & df2 & Sig. F Change \\
\hline 1 & $.458^{\mathrm{a}}$ & 75.314 & 1 & 89 & .000 \\
\hline
\end{tabular}

a. Predictors: (Constant), Participation in EE

Source: Field Survey 2020

Table 5 ANOVA $^{\mathrm{b}}$

\begin{tabular}{|ll|lr|l|l|l|l|}
\hline \multicolumn{2}{|l|}{ Model } & $\begin{array}{l}\text { Sum } \\
\text { Squares }\end{array}$ & of & Df & Mean Square & F & Sig. \\
\hline 1 & Regression & 8.656 & 1 & 8.656 & 75.314 & $.000^{\text {a }}$ \\
& Residual & 10.229 & 89 & .115 & & \\
Total & 18.884 & 90 & & & \\
\hline
\end{tabular}

a. Predictors: (Constant), Participation in EE

b. Dependent Variable: Career Reflections

Source: Field Survey 2020

\section{Interpretation of results}

The results from the model summary table above revealed that the extent to which the variance in Career Reflections can be explained by Participation in EE planning is $36.3 \%$ i.e (R square $=0.458$ ). The ANOVA table shows the Fcal 75.314 at 0.0001 significance level. Participation in EE significantly affect Career Reflections.

Table 6 Coefficients ${ }^{\mathrm{a}}$

\begin{tabular}{|c|c|c|c|c|c|c|}
\hline & & \multicolumn{2}{|c|}{$\begin{array}{l}\text { Unstandardized } \\
\text { Coefficients }\end{array}$} & \multirow{2}{*}{\begin{tabular}{|l}
$\begin{array}{l}\text { Standardized } \\
\text { Coefficients }\end{array}$ \\
Beta
\end{tabular}} & \multirow[b]{2}{*}{$\mathrm{T}$} & \multirow[b]{2}{*}{ Sig. } \\
\hline \multicolumn{2}{|c|}{ Model } & B & Std. Error & & & \\
\hline \multirow[t]{2}{*}{1} & (Constant) & 1.895 & .266 & & 7.129 & .000 \\
\hline & Participation in EE & .565 & .065 & .677 & 8.678 & .000 \\
\hline
\end{tabular}

a. Dependent Variable: Career Reflections

Source: Field Survey 2020

The coefficient table above shows the simple model that expresses how Participation in EE affects Career Reflections. The model is shown mathematically as follows; $\mathrm{Y}=\mathrm{a}+\mathrm{bx}$ where $\mathrm{y}$ is business continuity and $\mathrm{x}$ is Participation in EE, $\mathrm{a}$ is a constant factor and $\mathrm{b}$ is the value of coefficient. From this table therefore, Career Reflections $=1.895+0.565$ Participation in EE. This means that for every $100 \%$ change in Career Reflections Participation in EE, the significance level below 0.01 implies a statistical confidence of above $99 \%$. This implies that Participation in EE affect Career Reflections. Thus, the decision would be to reject the null hypothesis ( $\mathrm{H} 0)$, and accept the alternative hypothesis $(\mathrm{H} 1)$. 


\section{Hypothesis 2}

$\mathbf{H}_{\mathbf{0}}$ : There is no relationship between EE and Students Intentions Towards Entrepreneurship and Intrepreneurship

Hı: There is a relationship between EE and Students Intentions Towards Entrepreneurship and Intrepreneurship

Table 7 Model Summary

\begin{tabular}{|c|c|c|c|c|c|}
\hline \multirow[b]{2}{*}{ Model } & \multicolumn{5}{|c|}{ Change Statistics } \\
\hline & $\begin{array}{l}\mathrm{R} \text { Square } \\
\text { Change }\end{array}$ & F Change & df1 & df2 & Sig. F Change \\
\hline 1 & $.100^{\mathrm{a}}$ & 9.871 & 1 & 89 & .002 \\
\hline
\end{tabular}

a. Predictors: (Constant), Students Intentions Towards

Entrepreneurship and Intrepreneurship

Source: Field Survey 2020

Table 8 ANOVA ${ }^{b}$

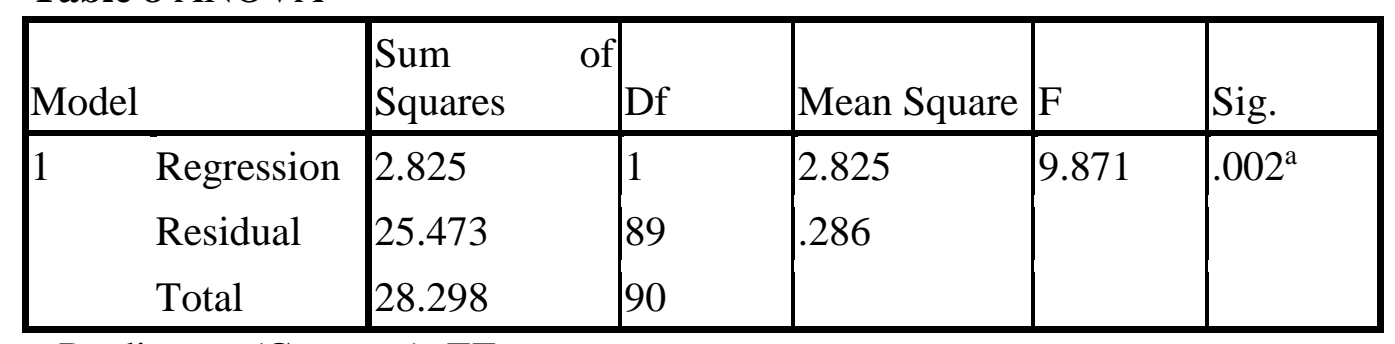

a. Predictors: (Constant), EE

b. Dependent Variable: Students Intentions Towards Entrepreneurship and Intrepreneurship

Source: Field Survey

\section{Interpretation of results}

The results from the model summary table above revealed that the extent to which the variance in Students Intentions Towards Entrepreneurship and Intrepreneurship can be explained by EE is $10.0 \%$ i.e. $(\mathrm{R}$ square $=0.100)$. The ANOVA table shows the Fcal 9.871 at 0.0001 significance level. EE significantly assists Students Intentions Towards Entrepreneurship and Intrepreneurship

Table 9 Coefficients

\begin{tabular}{|ll|l|l|l|l|l|}
\hline \multicolumn{2}{|c|}{} & \multicolumn{2}{|l|}{$\begin{array}{l}\text { Unstandardized } \\
\text { Coefficients }\end{array}$} & \multicolumn{2}{l|}{$\begin{array}{l}\text { Standardized } \\
\text { Coefficients }\end{array}$} & \\
\cline { 2 - 5 } & B & Std. Error & Beta & T & Sig. \\
\hline 1 & (Constant $)$ & 3.127 & .309 & & 10.131 & .000 \\
& EE & .227 & .072 & .316 & 3.142 & .002 \\
\hline
\end{tabular}

a. Dependent Variable: Students Intentions Towards

Entrepreneurship and Intrepreneurship

Source: Field Survey 2020 
The coefficient table above shows the simple model that expresses how EE affects Students Intentions Towards Entrepreneurship and Intrepreneurship . The model is shown mathematically as follows; $\mathrm{Y}=\mathrm{a}+\mathrm{bx}$ where $\mathrm{y}$ is Students Intentions Towards Entrepreneurship and Intrepreneurship and $\mathrm{x}$ is EE, $\mathrm{a}$ is a constant factor and $\mathrm{b}$ is the value of coefficient. From this table therefore, Students Intentions Towards Entrepreneurship and Intrepreneurship = $3.127+0.227 E E$. This means that for every $100 \%$ change in Students Intentions Towards Entrepreneurship and Intrepreneurship , EE contributed 22.7\%

\section{Discussion of findings}

This research has proved that Participation in EE significantly affect Career development and the emergence of vocational identity have consequently been established at the core of contemporary career theory. Progress towards career development and a vocational identity is of great importance in a person's life and a lack of progress can have severe consequences. Research shows that struggling with one's own career identity, being unemployed, and having an unfulfilling career have very negative effects on an individual's well-being. The time as a student in higher education should accordingly be one of self-exploration, change and growth in terms of both personal and career development. It is a time when it is important to engage in exploration of different career trajectories and to reflect upon one's future career opportunities The result of findings of this research is align with the findings Gielnik (2017); Atakpa (2011); Donnellon and Ollila (2014); Jones and Penaluna (2013); Gielnik et al, (2015); Bacigalupo et al, (2016) and Branson (2010).. The importance of career exploration and reflection implies that higher education needs to arrange activities that promote this among students; i.e., career interventions that trigger career development through exploration and reflection. Career counseling during tertiary education has been suggested as one means of career exploration that stimulates career development and so includes internships as integrated parts of higher education degrees. This paper investigated the potential of EE as a career exploration intervention and as an arena for career reflection. This research has proved that EE serves as a space for career reflection, where students learn more about themselves, about entrepreneurship, about the workplace, and about their opportunities in future careers. A common denominator of the outcome measure categories that are identified in this research is that they are all related to the careers of EE students. If knowledge, traits, skills, affective measures, conative measures and behavior can be impacted through participation in EE, this impact will have implications for students' future careers. Consequently, EE has the potential to impact how students behave in their future careers and how they reflect upon these. This research has proved that EE significantly assists Students Intentions towards Entrepreneurship and Intrepreneurship. The research has shown that Intrapreneurship is a career choice in which employees can be involved in entrepreneurial behavior and should accordingly also be addressed in the EE impact literature. The findings align with the findings of previous researchers such as Yildiz (2014); Okta et al, (2015); Brettel et al. (2015); Fayolle et al. (2010) and Shepherd et al. (2010) and Cherchem (2017). The findings revealed that EE is career exploration intervention that enables career reflection on career choice and future work selves. When students take part in EE, it can potentially be a process of transformational learning.

\section{Contributions and implications}

\section{Implications for practice}

The paper has implications for teachers and higher education institutions which develop, implement and teach EE courses, as well as for the students who take part in them. The view of $\mathrm{EE}$ as a career exploration intervention is a new one, but an important perspective to integrate in practice. For teachers, this perspective has implications for how teaching is planned and conducted. Being a teacher on EE courses entails great responsibility, as many courses tend to 
push the students out of their comfort zone. This provides an opportunity for growth through overcoming challenges (Krueger, 2017), but also adds the risk of students ending up in the panic zone and thereby dropping out of courses having experienced failure and feeling that they were not able to master the context. Hence, it becomes essential for EE teachers to balance the challenge and support aspects of EE courses. While challenges should not be avoided by any means, it is essential to ensure that these become opportunities for growth. Leaving time for reflection in class and between classes is important for the processing that is necessary to transform experience into knowledge, as described by Bell \& Bell (2016). Reflective activities should also include career reflection. As this paper provides empirical evidence of the potential of $\mathrm{EE}$ as a space for career reflection, it is important to include reflective activities that promote identity work, as suggested by Donnellon \& Ollila, (2014), Atakpa (2011) and Hytti \& Heinonen (2013), and that focus on the future application of experiences and learning for future careers. For educators, it is an important responsibility to introduce frames of reference that have a wide, rather than narrow perspective. Entrepreneurship should not be presented as only starting a company. Intrapreneurship and social entrepreneurship are also important arenas for entrepreneurial behavior and should be introduced to EE students (Hytti \& Heinonen, 2013). Thereby, a broader frame of reference is provided for students to develop future work selves from that are accessible for a larger share of them. This also needs to be reflected in the choice of role models and case descriptions to expand students' understanding of entrepreneurship as a career alterative. This can be particularly important for students who are led to career reconsideration after an $\mathrm{EE}$ course, in order to encourage further career exploration and new career commitments, instead of them remaining in a confused state of career indecisiveness. For students, it is important to make use of EE as an arena for individual career reflection and on the opportunities in the environment, regardless of whether they wish to become an entrepreneur or not. For higher education institutions, the value of $\mathrm{EE}$ for career development is an important issue to consider. Career development beyond the acquisition of knowledge and skills has been suggested as an important task for such institutions to prepare students for the 21st century work market (Kpoveta \& Agbomah, 2009). This can, for example, take place through career counseling services on campus, career days, guest lectures, collaboration on projects with external partners that could be future employers, as well as practical training through internships. Seeing EE as an activity in which the same mechanisms are at play is a novel perspective and one that must be included when higher education institutions are planning career development activities. Moreover, when implementing EE courses and programs, education institutions should ensure that they include activities that support career reflection among EE students beyond encouragement to pursue entrepreneurship.

\section{Implications for policy}

There has been a substantial growth in EE courses and programs worldwide in the recent decade, and much of this growth can be attributed to strategies by governments and policymakers (Valerio, Parton \& Robb., 2014). In the European Union, EE has been emphasized in the policy framework for education and training (Sanchez, 2013) through the definition of entrepreneurship as one of eight key competences for lifelong learning (Sanchez, 2013) and has become a priority in the EU's Europe 2020 strategy. In Nigeria there have been two dedicated EE policies to ensure its implementation at all education levels (Adenuga, 2009). In the Nigeria policies, there are two main objectives: 1) to learn business-specific competences for start-ups; and 2) to develop skills and attitudes through EE that can be in contexts beyond start-ups, for example in existing organizations, in volunteer work, in the cultural sector and through social entrepreneurship. However, there is no focus on whether the EE experience has implications for how students reflect about their careers. The policy's main focus is on the development of knowledge and skills, and on how to implement EE more widely at all study 
levels and in all study fields. With the insight from this study, a recommendation for Nigeria policymakers would be to include the perspective of $\mathrm{EE}$ as a career exploration intervention. This perspective has been missing from previous policies, although career development is an important task for young people and adolescents to prepare for the work market of the $21 \mathrm{st}$ century and needs to be included in policies. Policymakers' toolbox to stimulate career development has mainly limited itself to career counseling. Having EE as an additional opportunity for enhancing students' career development should provide additional benefits of EE beyond the acquisition of knowledge and skills. The findings on the marked methodological deficiencies in EE impact studies are also important for policymakers. The formulation of policies should be followed by evaluation of how the policies have been received, their impact and if there is room for improvement. In terms of following up the impact of EE initiatives quantitatively, this study provides evidence that indicates that this is not being measured appropriately. This is an important insight for policymakers in two ways. First, it is important to specify desired outcomes and targets that can serve as impact measures in policy, while also specifying rigorous impact criteria that need to be met in impact evaluations of policy. Second, the existing EE impact research that met the criteria of rigorous experimental design in the SLR paper did not comprise policy-initiated empirical studies. Conducting an impact study according to rigorous criteria is, however, a demanding task. Ideally, there should be large samples due to the requirements of both a treatment and a control group, and due to the occurrence of drop-out between pre-test and post-test. Moreover, it is beneficial to have samples from across regions and countries in order to enhance the generalizability of findings. Therefore, conducting rigorous impact studies is a demand on resources, both in terms of time and finances.

\section{Conclusion}

The study set out to explore whether EE has an impact on students' career reflections. The empirical findings of the papers suggest that the EE courses examined did so. Although EE convince students of careers as entrepreneurs of new companies, EE has a function and a career exploration intervention through which students have the chance to reflect upon themselves and their future careers. As described in RBV theory, career exploration becomes a space for reflection upon career choices and preferences, as well as future work selves. Students can thereby continue to either commit to or reconsider entrepreneurship as a career choice. In fact, the findings of the study are in line with several previous empirical studies that found that student intention significantly affect intrapreneurship. From a career development perspective, this is however not surprising if EE is seen as an arena for career reflection. Students might decide to commit to entrepreneurship after an EE course, or they might choose to reconsider, but as a result of the career reflection they will be able to make more informed decisions about their future careers and have a clearer view of the opportunities that exist. This demonstrates the importance of viewing EE through a career development lens and suggests a rewarding direction for further research. The study should accordingly be viewed as a contribution to expanding the field of EE impact research by emphasizing the comprehensiveness of EE career impact and the potential of career development theory.

\section{Limitations and Future Research}

However, making a choice to pursue one outcome also necessitates the dismissal of others. As the SLR paper shows, there are many different outcomes to study and several of these would have been interesting to study in the EE courses included in this paper. Hence, the concentration on EE career impact is not an indication of other outcome measures being less important. Referring to the SLR paper again, it is apparent that there is a need for a larger pool of EE impact studies, as called for by, for example, Fayolle \& Gailly (2015). The study has its limitations through the context of the studies, the methodologies applied and through the 
decisions that have been made regarding the theoretical framework. Nevertheless, I believe that it serves as a first step towards closer integration of $\mathrm{EE}$ and career development theory, and that it thereby contributes novel insight to a research field that is in need of stronger theoretical foundations.

\section{References}

Adenuga, O., (2011.) Developing Entrepreneurial Skills among the Youth: An antidote for National Insecurity, The Lagos Counsellor, 8 (1), 117-126.

Adenuga, O., (2009). Bullying at workplace: The Coping Strategies, African Journal of Research in Personnel and Counselling Psychology, 11 (6), 2-24.

Akinbola, O., Sanni, S., \& Akinbola, S. (2018). Appraisal of Entrepreneurship Capacity Programs and Internationalization of Small and Medium Enterprises in Nigeria, Acta Universitatis Danubius, 14 (6), 72-89.

Akinbola, O., Ogunnaike, O., \& Amaihian, A. (2015). Influence of Contextual Factors on Entrepreneurial Intention of University Students: The Nigerian Experience. Journal of South African Business Research 2015, 6(4), 2-24

Atakpa, R. (2011). Entrepreneurship Education: A Sine Qua-non in Business Education in Nigeria. Book of Readings, Association of Business Educators of Nigeria (ABEN), 1 (11), 1336.

Branson, C. (2010). Tips for Entrepreneurial Success. Sunday Punch, July, 18.

Bacigalupo, M., Kampylis, P., Punie, Y., \& Van den Brande, G. (2016), EntreComp: The entrepreneurship competence framework. Publication Office of the European Union, 4 (3), 33 56.

Bae, T. J., Qian, S., Miao, C., \& Fiet, J. O. (2014). The relationship between entrepreneurship education and entrepreneurial intentions: a meta-analytic review. Entrepreneurship Theory and Practice, 38 (2), 217-254.

Baumol, J., \& Strom, R. (2007). Entrepreneurship and economic growth. Strategic Entrepreneurship Journal, 1 (3), 233-237.

Bell, R., \& Bell, H. (2016). An enterprise opportunity for entrepreneurial students: Student enterprise development and experience assessed through the student voice. Education + Training, 58 (7), 751-765.

Brettel, M., Chomik, C., \& Flatten, T. (2015). How organizational culture influences innovativeness, proactiveness, and risk-taking: Fostering entrepreneurial orientation in SMEs. Journal of Small Business Management, 53(4), 868-885.

Cherchem, N. (2017). The relationship between organizational culture and entrepreneurial orientation in family firms: Does generational involvement matter? Journal of family business strategy, 8(2), 87-98.

Creswell, J. (2009). Educational research Planning, conducting and evaluating quantitative and qualitative research. (2nd Ed) Upper Saddle River, N.J: Pearson Education.

Donnellon, A., Ollila, S., \& Middleton, K. (2014). Constructing entrepreneurial identity in entrepreneurship education. The International Journal of Management Education, 12(3), 490499. 
Douglas, E., \& Fitzsimmons, J. (2013). Intrapreneurial intentions versus entrepreneurial intentions: distinct constructs with different antecedents. Small Business Economics, 41 (1), 115-132.

Easterby-Smith, M., Thorpe, R., \& Jackson, P. (2011). Management Research. London, SAGE Publications.

Elert, N., Andersson, F. W., \& Wennberg, K. (2015) The impact of entrepreneurship education in high school on long-term entrepreneurial performance. Journal of Economic Behavior \& Organization, 1(11), 209-223.

Fayolle, A. (2013). Personal views on the future of entrepreneurship education, Entrepreneurship \& Regional Development, 25 (8), 692-701.

Fayolle, A., \& Gailly, B. (2015). The impact of entrepreneurship education on entrepreneurial attitudes and intention: Hysteresis and persistence. Journal of Small Business Management, 53 (1), 75-93.

Fayolle, A., Basso, O., \& Bouchard, V. (2010) Three levels of culture and firms'entrepreneurial orientation: A research agenda. Entrepreneurship and Regional Development, 22(8), 707-730.

Fretschner, M., \& Lampe, H. W. (2018). Detecting hidden sorting and alignment effects of entrepreneurship education. Journal of Small Business Management, Advance online publication, 2(6), 60-84.

Gielnik, M., Frese, M., Kahara-Kawuki, A., Katono, I. W., Kyejjusa, S., Ngoma, M., \& Orobia, L. (2015). Action and action-regulation in entrepreneurship: Evaluating a student training for promoting entrepreneurship. Academy of Management Learning \& Education, 14 (1), 69-94.

Gielnik, M. M., Uy, M. A., Funken, R., \& Bischoff, M. (2017). Boosting and sustaining passion: A long-term perspective on the effects of entrepreneurship training. Journal of Business Venturing, 32 (3), 334-353.

Giddings, L., \& Grant, B. (2006). Mixed methods research for the novice researcher. Contemporary Nurse, 23(1), 3-11.

Gál, M. I. (2018). Leadership-Organizational Culture in the light of Public Management reform models $=$ Leadership-Szervezeti kultúra, a közmenedzsment reformok fényében (Doctoral dissertation, Budapesti Corvinus Egyetem). 33(4), 17-41.

Gill, J., \& Johnson, P. (2010). Research methods for managers. Sage.

Garba, A., (2010). Refocusing Education System Towards Entrepreneurship Development in Nigeria: A Tool for Poverty Eradication. European Journal of Social Sciences, (1), .3461.

Hair, J., Black, W., Babin, B., \& Anderson, R. (2014). Multivariate data analysis. Pearson Education Limited, Harlow, UK.

Hytti, U., \& Heinonen, J. (2013). Heroic and humane entrepreneurs: identity work in entrepreneurship education. Education + Training, 55 (8), 886-898.

Jones, C., \& Penaluna, A. (2013). Moving beyond the business plan in enterprise education. Education + Training, Vol. 5, (19), 804-814.

Karlsson, T., \& Moberg, K. (2013). Improving perceived entrepreneurial abilities through education: Exploratory testing of an entrepreneurial self-efficacy scale in a pre-post setting. The International Journal of Management Education, 11(1), 1-11. 
Kowo, S., Sabitu, O., \& Adegbite, A. (2018). Influence of Competitive Strategies on Corporate Performance of Small and Medium Enterprises. A case from Nigeria Agricultural and Resource Economics International Scientific Journal, 4 (3), 32-58.

Kowo, S. A, \& Adenuga, O. (2019). Correlates of Entrepreneurship Education and Employment Generation Economic and Social Development: Book of Proceedings, 342-369.

Kalmuk, G., \& Acar, A. (2015). The effect of quality orientation and learning orientation on firm performance. Research Journal of Business and Management, 2(4), 455-487.

Kellermanns, F., Walter, J., Crook, R., Kemmerer, B., \& Narayanan, V. (2016). The resourcebased view in entrepreneurship: A content-analytical comparison of researchers' and entrepreneurs' views. Journal of Small Business Management, 54(1), 26-48.

Kuratko, D., Hornsby, J., \& Bishop, J. (2005). Managers' corporate entrepreneurial actions and job satisfaction. The International Entrepreneurship and Management Journal, 1(3), 275-291.

Kpoveta, B., \& Agbomah, D. (2009). Entrepreneurship Development and Skill Acquisition Schemes as Tools for Youth Self-Employment, Economic Empowerment and National Development. Journal of Industrial and Technological Research, 23 (3), 52-77.

Krueger, N. F. (2017). Entrepreneurial intentions are dead: Long live entrepreneurial intentions. in Carsrud, A. \& Brännback, M. (Eds.), Understanding the entrepreneurial mind, Springer, New York, NY, 51-72.

Longva, K., \& Strand, O. (2018). Comparing career preferences of regionally oriented and internationally oriented students - a mixed method study, 22-45.

Hogset, H., Berge, D. M., \& Dale, K. Y. (2018). Detregionale i det internasjonale Fjordantologien, Universitetsforlaget. Oslo, Norway, 267-294.

Lorz, M., Mueller, S., \& Volery, T. (2013). Entrepreneurship education: a systematic review of the methods in impact studies. Journal of Enterprising Culture, 21 (2), 123-151.

Moberg, K., Vestergaard, L., Fayolle, A., Redford, D., Cooney, T., Singer, S., \& Filip, D. (2014). How to assess and evaluate the influence of entrepreneurship education: A report of the ASTEE project with a user guide to the tools, The Danish Foundation for EntrepreneurshipYoung Enterprise, Copenhagen, Denmark, 29 (4), 82-99.

Nabi, G., Liñan, F., Fayolle, A., Krueger, N., \& Walmsley, A. (2017). The impact of entrepreneurship education in higher education - a systematic review and research agenda. Academy of Management Learning \& Education, 16 (2), 277-299.

Nabi, G., Walmsley, A., Liñán, F., Akhtar, I., \& Neame, C. (2018). Does entrepreneurship education in the first year of higher education develop entrepreneurial intentions? The role of learning and inspiration, Studies in Higher Education, 43 (3), 452-467.

Ojeaga, J., \& Owolabi, I. (2011). Entrepreneurship Education as a Panacea for Reducing Unemployment and Poverty Among Business Education Graduates. Book of Readings, Association of Business Educators of Nigeria (ABEN) 1(11).

Oviawe, J.,\& Anarberokhai, M. (2008). The Role of Entrepreneurship Education in the Realization of the National Economic Empowerment and Development Strategy (NEEDS). Technical and Vocational Education Journal, 1(1), 57-65.

Okta, K., Umar, N., Musadiq, A., \& Hamidah, N. (2015). The Influence of Organizational Culture and EntrepreneurialOrientation on the Job Satisfaction, Organizational Commitment and Employee's Performance. European Journal of Business and Management, 7(2), 55-67. 
Peteraf, M. (1993). The cornerstones of competitive advantage: A resource based view. Strategic management journal, 14(3), 179-191.

Sharma, P., \& Chrisman J. (1999). Toward a Reconciliation of the Definitional Issues in the Field of Corporate Entrepreneurship. Entrepreneurship: Theory \& Practice, 23(3), 11-27.

Shepherd, D., Patzelt, H., \& Haynie, J. (2010). Entrepreneurial spirals: Deviation-amplifying loops of an entrepreneurial mindset and organizational culture. Entrepreneurship theory and practice, 34(1), 59-82.

Rauch, A., \& Hulsink, W. (2015). Putting entrepreneurship education where the intention to act lies: An investigation into the impact of entrepreneurship education on entrepreneurial behavior. Academy of Management Learning \& Education, 14(2), 187-204.

Sánchez, J. (2013). The impact of an entrepreneurship education program on entrepreneurial competencies and intention. Journal of Small Business Management, 51 (3), 447- 465.

Valerio, A., Parton, B., \& Robb, A. (2014). Entrepreneurship education and training programs around the world: dimensions for success, World Bank Publications, Washington, DC.

Yildiz, M. (2014). The effects of organizational culture on corporate entrepreneurship. International journal of business and social science, 5(5), 35-44.

Zampetakis, L., Lerakis, M., Kafetsios, K., \& Moustakis, V. (2015). Investigating the emotional impact of entrepreneurship programs. Journal of Business Venturing Insights, 2(4), 38- 41. 